\title{
Perception about Bacterial Vaginosis: A Common Vaginal Infection
}

\author{
Obubu Maxwell* \\ Department of Statistics, Nnamdi Azikiwe University, Nigeria
}

*Corresponding author: Obubu Maxwell, Department of Statistics, Nnamdi Azikiwe

University, Awka, Nigeria.

Received Date: July 11, 2019

Published Date: July 16, 2019

\begin{abstract}
The objective of the study was the perception of Bacterial vaginosis amongst female residents of Lagos State, Nigeria. Bacterial vaginosis is the most common vaginal infection found in women of reproductive age, caused by an imbalance in the natural vaginal flora. 200 women participated in the study, of which 132 women representing $69 \%$ of the participants have experienced Bacterial vaginosis at some point. 52 women had symptoms ranging from smelly vagina discharge after sexual intercourse to grey or whitish vaginal discharge. The women identified vaginal douching as the major risk factor of Bacteria vaginosis. 51.43\% of the participants responded to have treated Bacterial vaginosis using Metronidazole (Flagyl).
\end{abstract}

Keywords: bacterial vaginosis, metronidazole, vagina douching, smelly vagina discharge, unprotected sex, vagina deodorant, multiple female sex partners.

\section{Introduction}

Bacterial vaginosis (BV) is a type of vaginal inflammation caused by natural overgrown bacteria in the vagina that disturbs the natural balance. Healthy bacteria (lactobacilli) typically outweigh poor bacteria (anaerobes). But if too many anaerobic bacteria are present, they upset the vagina's microorganism natural balance and trigger bacterial vaginosis. Bacterial vaginosis is usually associated with women of reproductive age. There are over 1.5 million instances reported annually in Nigeria, although it is prevalent but poorly understood. Bacterial vaginosis normally does not cause vaginal pain or itching, but often produces abnormal vaginal discharge. While it is not fully understood the cause, certain activities, such as, having an Intrauterine device fitted for birth control, using vaginal deodorant, using scented soaps or bubble baths, cigarette smoking, and having unprotected sex, with a new sexual partner or multiple sexual partners, may increase a person's risk. Bacterial vaginosis is more prevalent in women who use a contraceptive coil and those who perform vaginal douching (washing the vagina). Don't douche [1-5]. Wipe from front to back, from the vagina to the anus when you go to the bathroom. Clean after every use of sex toys. Limit the amount of people you have sex with, and, use only water, not even soap, when you scrub your genital region to reduce the likelihood of getting Bacterial vaginosis. Generally speaking, Bacterial vaginosis does not trigger complications. Bacterial vaginosis can sometimes contribute to: preterm birth (premature birth, low birth weight or miscarriage), sexually transmitted diseases, risk of infection following gynecological surgery, and pelvic inflammatory disease. Bacterial vaginosis is generally not considered as a sexually transmitted infection (STI). There is inconsistent proof on the topic, though. Evidence suggesting that Bacterial vaginosis may be an STI includes: higher Bacterial vaginosis rates in women who have multiple sexual partners, lower Bacterial vaginosis rates in women who use condoms during sex. There is also proof that women with Bacterial vaginosis are able to transfer the disease to women with whom they have sex, although it is still uncertain how this occurs. However, there is also evidence to suggest that Bacterial vaginosis may not be an STI, as: there is no equivalent of Bacterial vaginosis in men, treating male partners with antibiotics does not prevent Bacterial vaginosis from recurring, bacterial vaginosis rates can vary substantially across different ethnic groups, which cannot be explained by sexual activity alone [6-10]. In women who are not sexually active, Bacterial vaginosis may sometimes occur. Many experts think that sexual activity plays a role in Bacterial vaginosis, but other factors is also likely to be responsible for the condition. Antibiotics such as Metronidazole can effectively treat Bacterial vaginosis (BV). Vaginal $\mathrm{pH}$ correction treatments are also accessible. 
The objective of the present study was the perception of Bacterial vaginosis disease amongst female residents in Lagos State, Nigeria.

\section{Material and Methods}

Since it was survey, no scientific method was available. We met with the female residents for their perception and awareness of Bacterial vaginosis and consented to them whether or not they know about Bacterial vaginosis. Most of the women involved in the study knew about Bacterial vaginosis, have experienced it at one point or the other, and/or have family members who have experienced the condition. They knew that Bacterial vaginosis often causes unusual vaginal discharge which they described as whitish, watery, and with a strong rotten fish smell, particularly after sexual intercourse, although a few number of the women said they showed no symptoms to Bacterial vaginosis. Many of the women classified Bacterial vaginosis as a sexually transmitted infection and admitted to have treated the condition using Flagyl (Metronidazole). A total 200 women participated in this study.

\section{Result and Discussion}

(Table 1)

Table 1: Age group of respondents.

\begin{tabular}{|c|c|c|}
\hline Age Group & Count & Frequency \\
\hline $20-25$ & 25 & $12.5 \%$ \\
\hline $26-31$ & 60 & $30 \%$ \\
\hline $32-37$ & 65 & $32.5 \%$ \\
\hline $38-43$ & 40 & $20 \%$ \\
\hline $44+$ & 10 & $5 \%$ \\
\hline Total & 200 & $100 \%$ \\
\hline
\end{tabular}

Have you heard about Bacterial vaginosis disease? (Table 2)

Table 2: Questionnaire to evaluate knowledge on bacterial vaginosis.

\begin{tabular}{|c|c|c|}
\hline Response & Count & Frequency \\
\hline Yes & 175 & $87.50 \%$ \\
\hline No & 25 & $12.50 \%$ \\
\hline Total & 200 & $100 \%$ \\
\hline
\end{tabular}

From Table 2, we conclude that most people know about Bacterial vaginosis but some were hearing about it for the first time. Ever go through Bacterial vaginosis? (Table 3)

Table 3: Questionnaire to evaluate past experience with Bacterial vaginosis.

\begin{tabular}{|c|c|c|}
\hline Response & Count & Frequency \\
\hline Yes & 138 & $69.00 \%$ \\
\hline No & 37 & $18.50 \%$ \\
\hline No Idea & 25 & $12.50 \%$ \\
\hline Total & 200 & $100 \%$ \\
\hline
\end{tabular}

From Table 3, we clearly see that of the 200 women involved in the study, 138 of the women have experience Bacterial vaginosis, 37 women have not experience the vaginal infection, and 25 women has no idea whether or not they have ever gone through Bacterial vaginosis.

Have any of your Family members ever gone through Bacterial vaginosis? (Table 4)
Table 4: Questionnaire to evaluate Family history with Bacterial vaginosis.

\begin{tabular}{|c|c|c|}
\hline Response & Count & Frequency \\
\hline Yes & 120 & $60.00 \%$ \\
\hline No & 55 & $27.50 \%$ \\
\hline No Idea & 25 & $12.50 \%$ \\
\hline Total & 200 & $100 \%$ \\
\hline
\end{tabular}

From Table 4, we clearly see that of the 200 women involved in the study, 120 of the women admitted that a family member have experienced Bacterial vaginosis, 25 women responded that none of their family member have experienced the vaginal infection, and 25 women has no idea.

Did you experience any symptoms with Bacterial vaginosis? (Table 5)

Table 5: Observation of signs and symptoms of Bacterial vaginosis.

\begin{tabular}{|c|c|c|}
\hline Response & Count & Frequency \\
\hline Yes & 52 & $37.68 \%$ \\
\hline No & 86 & $62.32 \%$ \\
\hline Total & 138 & $100 \%$ \\
\hline
\end{tabular}

From Table 5, we clearly see that of the 138 women who have experienced Bacterial vaginosis, 52 of them admitted that experienced different symptoms of the infection, while 86 women did not experience any symptoms (Table 6).

Table 6: Symptoms Experienced.

\begin{tabular}{|c|c|c|}
\hline Response & Count & Frequency \\
\hline $\begin{array}{c}\text { Smelly Vagina Discharge after Sexual } \\
\text { Intercourse }\end{array}$ & 29 & $55.77 \%$ \\
\hline Itching & 0 & $0.00 \%$ \\
\hline Thin or Watery & & \\
\hline Vagina Discharge & 5 & $9.62 \%$ \\
\hline Grey or Whitish Vagina Discharge & 3 & $5.76 \%$ \\
\hline Abnormal amount of Vagina Discharge & 10 & $19.23 \%$ \\
\hline Pain with Sexual Intercourse & 5 & $9.62 \%$ \\
\hline Pelvic Pain & 0 & $0.00 \%$ \\
\hline Fever & 0 & $0.00 \%$ \\
\hline Total & 52 & $100 \%$ \\
\hline
\end{tabular}

Table 7: Risk Factors of Bacterial Vaginosis.

\begin{tabular}{|c|c|c|}
\hline Response & Count & Frequency \\
\hline Multiple Female Sexual Partners & 15 & $8.57 \%$ \\
\hline Vagina Douching & 65 & $37.14 \%$ \\
\hline Smoking & 5 & $2.86 \%$ \\
\hline Unprotected Sex & 5 & $2.86 \%$ \\
\hline Vagina Deodorant & 55 & $31.43 \%$ \\
\hline Scented soap and/or bubble bath & 30 & $17.14 \%$ \\
\hline Total & 175 & $100 \%$ \\
\hline
\end{tabular}

Table 6 shows that of the 52 women who experienced some form of symptoms, 29 women representing $55.77 \%$ responded to have experienced smelly vagina discharge after sexual intercourse, $19.23 \%$ of the women experienced abnormal amount of vaginal discharge, $9.62 \%$ of the women experienced pain during sexual intercourse, and thin or watery vagina discharge. None of the women experienced itching, pelvic pain or fever. What are the 
risk factors that can increase the chances of developing Bacterial vaginosis? (Table 7)

From the 175 women who responded to have experience Bacterial vaginosis, 65 women representing 37.14\% responded that Vagina Douching is one of the significant risk factors that could possible increase the chances of developing Bacterial vaginosis. 55 women representing $31.43 \%$ cited Vagina deodorant as one of the possible risk factors, $17.14 \%$ of the women attributed the chances of developing Bacterial vaginosis to washing with scented soap and having a bubble bath, $8.57 \%$ of the women Multiple female sexual partners as a risk factor, while $2.86 \%$ of the women identified unprotected sex, smoking of cigarette as some of the other possible risk factors. Is Bacterial vaginosis sexually transmitted? (Table 8)

Table 8: Transmission of Bacterial Vaginosis.

\begin{tabular}{|c|c|c|}
\hline Response & Count & Frequency \\
\hline Yes & 25 & $14.29 \%$ \\
\hline No & 130 & $74.28 \%$ \\
\hline Not Certain & 20 & $11.43 \%$ \\
\hline Total & 175 & $100 \%$ \\
\hline
\end{tabular}

From the 175 women who responded to have experience Bacterial vaginosis, 130 women representing 74.28\% responded that Bacterial vaginosis is not sexually transmitted, 25 women representing 14.29\% however responded that Bacterial vaginosis is sexually transmitted, while $11.43 \%$ of the women were not certain. What medicine treats Bacterial vaginosis disease? (Table 9)

Table 9: Treatment of Bacterial Vaginosis.

\begin{tabular}{|c|c|c|}
\hline Response & Count & Frequency \\
\hline Metronidazole (Flagyl) & 90 & $51.43 \%$ \\
\hline Herbal Medicine & 28 & $16.00 \%$ \\
\hline Yoghurt Probiotic & 2 & $1.14 \%$ \\
\hline Vaginal Clindamycin Cream & 20 & $11.43 \%$ \\
\hline Tinidazole (Tindamax) & 35 & $20.00 \%$ \\
\hline Total & 175 & $100 \%$ \\
\hline
\end{tabular}

Of the 175 women, $51.43 \%$ responded to have treated Bacterial vaginosis using Metronidazole and 20\% responded to have taken Tinidazole antibiotics. $16 \%$ of the women used homemade herbal recipe for the treatment of Bacterial vaginosis, $11.43 \%$ made use of Vaginal Clindamycin cream, while $1.14 \%$ treated Bacterial vaginosis using Yoghurt probiotics.

\section{Conclusion}

Though common among women of childbearing age, Bacterial vaginosis is not a condition to be ignored. Women are well informed about Bacterial vaginosis, and they also know that the condition can be treated with the use of antibiotics.

\section{Acknowledgement}

None.

\section{Conflict of Interest}

No conflict of interest.

\section{References}

1. Javed A, Parvaiz F, Manzoor S (2019) Bacterial vaginosis: An insight into the prevalence, alternative treatments regimen and it's associated resistance patterns. Microb Pathog 127: 21-30.

2. Adane Bitew, Yeshiwork Abebaw, Delayehu Bekele, Amete Mihret (2017) Prevalence of Bacterial Vaginosis and Associated Risk Factors among Women Complaining of Genital Tract Infection. International Journal of Microbiology: 8.

3. Catriona S Bradshaw, Jack D Sobel (2016) Current Treatment of Bacterial Vaginosis-Limitations and Need for Innovation, The Journal of Infectious Diseases 214(suppl 1): S14-S20.

4. Amsel R, Totten PA, Spiegel CA, Chen KC, Eschenbach D, et al. (1983) Nonspecific vaginitis. Diagnostic criteria and microbial and epidemiological associations. Am J Med. 74:14-22.

5. Koumans EH, Sternberg M, Bruce C, McQuillan G, Kendrick J, et al. (2007) The prevalence of bacterial vaginosis in the United States, 2001-2004; associations with symptoms, sexual behaviors, and reproductive health. Sex Transm Dis 34(11): 864-869.

6. Bradshaw CS, Vodstrcil LA, Hocking JS, Law M, Pirotta M, et al. (2013) Recurrence of bacterial vaginosis is significantly associated with post treatment sexual activities and hormonal contraceptive use. Clin Infect Dis 56(6): 777-786.

7. Taylor BD, Darville T, Haggerty CL (2013) Does bacterial vaginosis cause pelvic inflammatory disease. Sex Transm Dis 40(2): 117-122.

8. Sobel R, Sobel JD (2015) Metronidazole for the treatment of vaginal infections. Expert Opin Pharmacother 16(7): 1109-1115.

9. Brotman RM, Klebanoff MA, Nansel TR, Kai F. Yu,2 William W. Andrews, et al. (2010) Bacterial vaginosis assessed by gram stain and diminished colonization resistance to incident gonococcal, chlamydial, and trichomonal genital infection. J Infect Dis 202(12): 1907-1915.

10. Cohen CR, Lingappa JR, Baeten JM, Ngayo MO, Spiegel CA, et al (2012) Bacterial vaginosis associated with increased risk of female-to-male HIV-1 transmission: a prospective cohort analysis among African couples. PLoS Med 9(6): e1001251. 